\title{
The Effect of a Recreational Healthy Program with a Food Supplement on Physiological Measurements \& Old People's Life Quality
}

\author{
Prof. Dr./ ALAA ELDIN MOHAMED ELiWA ${ }^{1}$ \\ Assistant Prof. Dr./ SAFWAT ALY GOMAA ${ }^{2}$ \\ Researcher/ NASHWA MOHAMED GOADAR ${ }^{3}$ \\ Research Abstract:
}

The study aims at identifying the effect of a healthy recreational program with a food supplement on old people's life quality through combining a healthy recreational program with a food supplement and identifying the effect of the suggested program on some physiological variables (cholesterol - triglycerides - useful cholesterol - harmful cholesterol - cretin - totl lipids - fasting sugar - Glycated hemoglobin - urea - hemoglobin - red blood corpuscles - hematocrit - white platelets - tars - nonantioxidant W.B.CsTOTL) and identifying the effect of the suggested program on the old people's life quality, the researchers used the experimental method and the study sample included 20 old person, and data collection tools were (physiological variables measurements - life quality scale - healthy recreational program with a food supplement), the study results proved improvement in the studied physiological variables, also old people's life quality improved.

\section{The Study Introduction and Problem:}

The most difficult time for living organism is ageing time as characterized by deterioration and general weakness in terms of fulfilling the life tasks, whether physically, mentally, or socially as the aged needs help to be able to achieve main requirements, which became tiresome after he was able to fulfill many tasks.

Many old people suffer from psychological, physical and social problems in their lives, which are always ignored (although they are dangerous) as a result of many considerations the old person's disability and physical performance weakness in addition to his or his sponsor's disability to bear costs of medication, or disability to take any preventive

\section{Study Terminology:}

* Healthy Recreational Program:

A recreational activities and games program, though which a food supplement is taken as these activities and games are identified according to the selected study sample. (Procedural Definition)

* Food Supplement:

${ }^{1}$ Professor of Sports Health, Department of Biological Sciences and Sports Health Faculty of Physical Education for Boys - Alexandria University.

2 Assistant Professor, Sports Administration and Recreation - Faculty of physical Education for Boys - Alexandria University.

${ }^{3}$ Researcher, Department of Biological Sciences and Sports Health - Faculty of Physical Education for boys- Alexandria University. 
Linen seeds at (30) grams a day subdivided to (10) grams for every person in every unit as decided by researches and studies to be powdered and taken by water only with no additions. (Procedural Definition)

\section{* Old People's Life Quality:}

Old people's feelings of accepting their lives due to their health improvement through improving their studied physiological variables and applying recreational activities and games. (Procedural Definition)

\section{Study Objective:}

The research aims at identifying the effect of a healthy recreational program with a food supplement on the old people's life through the following:

1. Establishing a health recreational program with a food supplement.

2. Identifying the effect of the suggested program on some physiological variables (cholesterol - triglycerides - useful cholesterol - harmful cholesterol - cretin - totl lipids - fasting sugar - Glycated hemoglobin - urea - hemoglobin - red blood corpuscles - hematocrete - white platelets - tbrs - totlntioxidnt - W.B.CsTOTL)

3. Identifying the effect of the suggested program on the old people's life

\section{Study Hypotheses:}

1. Statistical significant difference between pre and post test in some physiological variables (cholesterol - triglycerides - useful cholesterol - harmful cholesterol cretin - totl lipids - fasting sugar - Glycated hemoglobin - urea - hemoglobin - red blood corpuscles - hematocrete - white platelets - tbrs - totlntioxidnt - W.B.CsTOTL) in the interest of post test.

2. Statistical significant difference between pre and post test in life quality in the interest of post test.

\section{Study Procedures:}

\section{Study Method:}

The experimental method by using pre and post test.

\section{Study Scopes:}

Time scope: 2019 - 2020, as pre tests were made on 14/06/2019 and the program was applied from 01/10/2019 to 31/12/2019 and post tests were made on 01/01/2020.

Spatial scope: El Haramen Youth Centre related to Youth and Sports Directorate, Alexandria.

\section{Study Sample:}

(30) women were selected deliberately from El Haramen Youth Centre members ageing between (45 - 55) years desiring to participate in the program given that they are free from endemic and dangerous diseases, that were subdivided to an experimental group, (20) women and (10) were selected randomly from inside the research community and outside the main study sample, to make to pilot study and coding the research tools.

\section{Data Collection Tools:}

Data collection tools were (measuring physiological variables - life quality scale healthy recreational program with a food supplement) as the researchers will discuss all these scales.

First: Physiological Scales:

* The Object of Physiological Scales: 
Identifying the effect of the suggested program on physiological variables.

* Identifying Physiological Measurements:

The researchers surveyed the literature in the field of old people to identify physiological measurements usable in the research which found that the most important physiological measurements are (cholesterol - triglycerides - useful cholesterol - harmful cholesterol - cretin - totl lipids - fasting sugar - Glycated hemoglobin - urea - hemoglobin - red blood corpuscles - hematocrete - white platelets - tbrs - totlntioxidnt W.B.CsTOTL) as no scientific coefficient s were made for these measurements as they were made at a certified lab though blood samples.

Second: Life Quality Scale, Attachment (1)

It was depended on life quality scale prepared by Abdelhalim Mansy, Aly Mahdy Kazim (2006) (18) as a tool for data collection and its statements were redrafted to suit the researched age as the research coefficients were made to make the research applicable. Scale Description:

The scale consists of (50) statements in front of which there is a three graded grades ranging between (Yes - to a certain degree - No) and consists of (5) factors: mental health from statement (1) to (10), public health from statement (11) to (20), family and social from statement (21) to (30), emotions from statement and emotions from statement (31) to (40) and making use of spare times from statement (41) to (50) and to verify that the scale is applicable, the researchers calculated the scale scientific coefficients represented in reliability an validity on the pilot study sample which is (10) women and out of the main study sample on 14/06/2019.

Scientific Coefficients of Life Quality Scale:

First Reliability:

Reliability of mind habits was verified by calculating Cronbach's Alpha reliability coefficient for statement $\mathrm{s}$ and factors and the grand total of the scale.

1- Program Contents:

By literature survey, the researchers found that the best means of improving old people's life quality is improving their health represented in improving their physiological variables and life quality, accordingly the researchers selected a food supplement, activities and games assisting in developing these aspects and putting in a form of health activity and recreational games inside the program, the researchers were keen to make the program consist of:

- Discussions between the researchers and the research sample.

- Recreational games am activities

- Food supplement

2- Program Time Table:

The program execution took (12) weeks with (36) units at (3) units a week as the unit time lasted for (90) minutes distributed as follows:

1. The first prefatory part: consisting of two parts:

- Administrative works: last for (5 minutes) as this part consists of absence and presence and preparing tools.

- Preparing the unit: lasts for (10 minutes) including preparing the (exercise with and without tools) and by using music.

2. Second part: Main: 
- Lasts for (60 minutes) and aims at executing the suggested program in which the researchers give the research sample a powdered linen seeds to be taken by the research sample in the presence of the researchers which is (10) grams for every subject to be taken with water only.

3. Third part: Final:

- It lasts for (15 minutes) and includes all tools and their order and giving a brief idea about the next unit.

Main Study:

The suggested program was applied from $01 / 10 / 2019$ to $31 / 12 / 2019$

Statistical Treatments:

Statistical treatments were used by using SPPS program.

Results \& Discussion:

First: Results :

Table (1)

Statistical Significance of Physiological Measurements and Change Percentage of

Pre and Post Test

\begin{tabular}{|c|c|c|c|c|c|c|c|c|}
\hline \multirow{2}{*}{$\begin{array}{l}\text { Statistical } \\
\text { Stgnificance }\end{array}$} & \multicolumn{2}{|c|}{ Pre Test } & \multicolumn{2}{|c|}{ Post Test } & \multicolumn{2}{|c|}{$\begin{array}{c}\text { Difference } \\
\text { between the } \\
\text { Two } \\
\text { Averages }\end{array}$} & \multirow[t]{2}{*}{$\begin{array}{c}\text { (T) } \\
\text { Value }\end{array}$} & \multirow[t]{2}{*}{$\begin{array}{c}\text { Change } \\
\text { Percentag } \\
\text { e } \\
\%\end{array}$} \\
\hline & $\mathbf{S}$ & $\mathrm{O} \pm$ & $\mathbf{S}$ & $\mathbf{O} \pm$ & $\mathbf{S}$ & $\mathrm{O} \pm$ & & \\
\hline Cholesterol & $\begin{array}{c}210.0 \\
0\end{array}$ & 6.51 & $\begin{array}{c}141.3 \\
5\end{array}$ & 7.02 & $\begin{array}{c}68.6 \\
5\end{array}$ & 6.93 & $* 44.30$ & $\% 32.69$ \\
\hline Triglycerides & $\begin{array}{c}174.1 \\
0\end{array}$ & $\begin{array}{c}10.7 \\
7\end{array}$ & $\begin{array}{c}131.2 \\
0\end{array}$ & 6.46 & $\begin{array}{c}42.9 \\
0\end{array}$ & 6.18 & *31.04 & $\% 24.64$ \\
\hline $\begin{array}{c}\text { Useful } \\
\text { Cholesterol }\end{array}$ & 25.80 & 2.88 & 62.05 & 5.51 & $\begin{array}{c}36.2 \\
5 \\
\end{array}$ & 3.21 & $* 50.51$ & $\% 140.50$ \\
\hline $\begin{array}{c}\text { Harmful } \\
\text { Cholesterol }\end{array}$ & 98.80 & 5.85 & 75.60 & 7.90 & $\begin{array}{c}23.2 \\
0\end{array}$ & $\begin{array}{c}12.7 \\
6\end{array}$ & $* 8.13$ & $\% 23.48$ \\
\hline Cretin & 1.32 & 0.14 & 0.75 & 0.13 & 0.57 & 0.04 & *56.98 & $\% 43.30$ \\
\hline Totl lipids & $\begin{array}{c}503.7 \\
0\end{array}$ & $\begin{array}{c}27.9 \\
1\end{array}$ & $\begin{array}{c}416.1 \\
5\end{array}$ & $\begin{array}{c}29.8 \\
3\end{array}$ & $\begin{array}{c}87.5 \\
5\end{array}$ & $\begin{array}{c}40.9 \\
5\end{array}$ & $* 9.56$ & $\% 17.38$ \\
\hline Fasting sugar & $\begin{array}{c}127.1 \\
0 \\
\end{array}$ & $\begin{array}{c}17.4 \\
1 \\
\end{array}$ & $\begin{array}{c}103.6 \\
0 \\
\end{array}$ & $\begin{array}{c}19.7 \\
2 \\
\end{array}$ & $\begin{array}{c}23.5 \\
0 \\
\end{array}$ & 6.53 & $* 16.11$ & $\% 18.49$ \\
\hline $\begin{array}{c}\text { Glycated } \\
\text { Hemoglobin }\end{array}$ & 6.17 & 1.35 & 5.64 & 1.17 & 0.54 & 0.29 & $* 8.34$ & $\% 8.67$ \\
\hline Urea & 46.50 & 5.06 & 24.75 & 3.13 & $\begin{array}{c}21.7 \\
5\end{array}$ & 2.55 & $* 38.11$ & $\% 46.77$ \\
\hline
\end{tabular}




\begin{tabular}{|c|c|c|c|c|c|c|c|c|}
\hline Hemoglobin & 10.50 & 0.51 & 12.98 & 0.67 & 2.48 & 0.46 & $* 24.14$ & $\% 23.62$ \\
\hline $\begin{array}{c}\text { Red blood } \\
\text { corpuscles }\end{array}$ & 3.38 & 0.18 & 4.65 & 0.28 & 1.26 & 0.19 & $* 29.67$ & $\% 37.31$ \\
\hline Hematocrete & 33.25 & 1.62 & 41.30 & 3.01 & 8.05 & 1.64 & $* 21.98$ & $\% 24.21$ \\
\hline $\begin{array}{c}\text { White } \\
\text { platelets }\end{array}$ & $\begin{array}{c}181.6 \\
5\end{array}$ & $\begin{array}{c}11.8 \\
8\end{array}$ & $\begin{array}{c}238.5 \\
5\end{array}$ & 7.18 & $\begin{array}{c}56.9 \\
0\end{array}$ & 6.24 & $* 40.78$ & $\% 31.32$ \\
\hline W.B.CsTOTL & 6.51 & 0.64 & 9.28 & 0.54 & 2.78 & 0.29 & $* 42.27$ & $\% 42.66$ \\
\hline Totlntioxidnt & 2.31 & 0.21 & 1.41 & 0.53 & 0.90 & 0.37 & $* 10.78$ & $\% 38.35$ \\
\hline Tbrs & 2.45 & 0.11 & 0.97 & 0.11 & 1.48 & 0.04 & $\begin{array}{c}* 154.2 \\
5\end{array}$ & $\% 60.47$ \\
\hline
\end{tabular}

* Significant at level $0.05=(09.2)$

It is clear from table number (1) of statistical significance of physiological measurements and change percentage for pre and post test: statistical difference at level $(0.05)$ as value of calculated $(\mathrm{t})$ ranged between (8.13 to 154.25$)$ which is a value greater than tabular $(\mathrm{t})$ at level $(0.05)=(2.09)$ at significant level less than 0.05 , and percentage of change in all physiological measurements ranged between $(8.67 \%$ to $140.50 \%)$ in the interest of post test.

Table (2)

Significance of Affecting Physiological Measurements according to Cohen's Equations

\begin{tabular}{|c|c|c|c|c|c|c|}
\hline Statistical Significance & $\begin{array}{c}\text { Least } \\
\text { Trust } \\
\text { Level }\end{array}$ & $\begin{array}{c}\text { Highest } \\
\text { Trust } \\
\text { Level }\end{array}$ & $\begin{array}{c}(\text { T) } \\
\text { Value }\end{array}$ & $\sum^{2}$ & Affection & $\begin{array}{c}\text { 1Affection } \\
\text { Significance }\end{array}$ \\
\hline Measurements & 65.41 & 71.89 & 44.30 & 0.99 & 10.12 & High \\
\hline Cholesterol & 40.01 & 45.79 & 31.04 & 0.98 & 3.68 & High \\
\hline Triglycerides & $37.75-$ & $34.75-$ & 50.51 & 0.99 & 5.20 & High \\
\hline Useful Cholesterol & 17.23 & 29.17 & 8.13 & 0.78 & 3.37 & High \\
\hline Harmful Cholesterol & 0.55 & 0.59 & 56.98 & 0.99 & 4.15 & High \\
\hline Cretin & 68.38 & 106.72 & 9.56 & 0.83 & 3.3 & High \\
\hline Totl lipids & 20.45 & 26.55 & 16.11 & 0.93 & 1.19 & High \\
\hline Fasting sugar & 0.40 & 0.67 & 8.34 & 0.79 & 0.33 & High \\
\hline Glycated Hemoglobin & 20.56 & 22.94 & 38.11 & 0.99 & 3.56 & High \\
\hline Urea & $2.70-$ & $2.26-$ & 24.14 & 0.97 & 4.0 & High \\
\hline Hemoglobin & $1.35-$ & $1.17-$ & 29.67 & 0.98 & 4.79 & High \\
\hline Red blood corpuscles & $8.82-$ & $7.28-$ & 21.98 & 0.96 & 1.92 & High \\
\hline Hematocrete & $59.82-$ & $53.98-$ & 40.78 & 0.99 & 4.05 & High \\
\hline White platelets & $2.91-$ & $2.64-$ & 42.27 & 0.99 & 4.47 & High \\
\hline W.B.CsTOTL & & & & & & \\
\hline
\end{tabular}




\begin{tabular}{|c|c|c|c|c|c|c|}
\hline Totlntioxidnt & 0.72 & 1.07 & 10.78 & 0.86 & 1.41 & High \\
\hline Tbrs & 1.46 & 1.50 & 154.25 & 1.00 & 13.75 & High \\
\hline
\end{tabular}

Affection: less than $0.5:$ low $0.5-0.8:$ average 0.8 or more $:$ high

From table (2) of significance of affecting physiological measurements according to Cohen's equations, it is clear that values of affecting all physiological measurements ranged between (1.19 to 13.75) which are higher than (0.8) accordingly the experimental variable effect in these measurements was high, while it was low in measuring ( $\mathrm{Hb} \mathrm{A} 1 \mathrm{C})$.

Table (3)

Statistical Significance of Total Factors and Grand Total of Factors of Life Quality Scale and Change Percentage for Pre and Post Test

\begin{tabular}{|c|c|c|c|c|c|c|c|c|}
\hline \multirow{2}{*}{$\begin{array}{l}\text { Statistical } \\
\text { Significance } \\
\text { Factors }\end{array}$} & \multicolumn{2}{|c|}{ Pre Test } & \multicolumn{2}{|c|}{ Post Test } & \multicolumn{2}{|c|}{$\begin{array}{c}\text { Difference } \\
\text { between the } \\
\text { Two } \\
\text { Averages }\end{array}$} & \multirow[t]{2}{*}{$\begin{array}{l}(\mathrm{T}) \\
\text { Value }\end{array}$} & \multirow[t]{2}{*}{$\begin{array}{c}\text { Change } \\
\text { Percentage } \\
\%\end{array}$} \\
\hline & $\mathbf{S}$ & $\mathbf{O \pm}$ & $\mathbf{S}$ & $\mathbf{O} \pm$ & $\mathbf{S}$ & $\mathbf{O} \pm$ & & \\
\hline Mental health & 18.30 & 636 & 2380 & 488 & 55 & & & $\% 3$ \\
\hline Public & 19 & & & & & & & $\% 12$ \\
\hline $\begin{array}{c}\text { Familial and } \\
\text { social }\end{array}$ & 5 & 6.29 & 0 & 6 & 0 & 2.56 & 1. & $\%$ \\
\hline Emo & 20. & & & & 1.20 & 1.7 & $* 3$. & $\% 5.78$ \\
\hline $\begin{array}{l}\text { Making use of } \\
\text { spare time }\end{array}$ & 0 & 6.07 & J & 9 & J.2J & 2. & 4 & 02 \\
\hline $\begin{array}{l}\text { Grand total } \\
\text { f factors }\end{array}$ & 97.95 & 30.51 & 110.90 & 24.90 & 12.95 & 11.15 & $* 5.20$ & $\% 13.22$ \\
\hline
\end{tabular}

* Significant at level $0.05=(09.2)$

From table number (3) of statistical significance of total factors an grand total of factors of life quality scale and percentage of change for pre and post test: statistical significant difference at level $(0.05)$ in the scale factors as calculated $(t)$ ranged between (3.15 to 6.02) which is higher than tabular $(\mathrm{t})$ at level $(0.05)=(2.09)$ and at significance level less than 0.05 while there no statistical significant difference in total family and social factors and the percentage of change in all life quality factors ranged between (3.16\% to $30.05 \%$ ) in the interest of post test.

\section{Second: Results Discussion}

From table number (3) and table number (4), there is an improvement in physiological measurements of old people (the research subject) as the researchers attribute these results to the suggested program and these results agree with results of study of Mohamed Ahmed Abdel Ghaffar (2019) (21) and Hossam Osama Abdel Moneim (2019) (12) which confirmed that recreational programs and food supplements have a positive effect on old people's physiological variables.

Nutrition plays an important role in human life, also health relates to food, as man is known through his food and physical health depends on what we eat and foods that differ according to age. $(26: 11)$ 
Food provides body with essentials of growth, reproduction and renewal, also food is and will remain the life basis, as many diseases such as fatness, heart and cancer has a direct relationship to food and healthy nutrition is moderation, variegation and balance of consumed and available food as there is no single food contains all nutritional elements.

Of the most important family's health role towards the old person is caring of his food, in terms of quantity and quality according to his advanced age, and considering taking medication on a permanent basis. Family is the main organization of care of old people health - specially women - as it provide them with medication expenses, which is an important affair for income less or low income group. Generally, old people's care depends on their family' circumstances. (24:48)

From table number (5), it was found that old people's life quality improved due to improvement in physiological measurements and the used recreational programs as these results agree with results of study of Mohamed Kamal Elsamanody et al (2017) (22) and study of Ahmed Aly Farag (2019) (3), to confirm that recreational programs have appositive effect on the life quality.

Recreation is an optional activity applied in spare time aiming at happiness and self content and develops one or more individual's aspect (physically, psychologically, socially, emotionally, morally and cognitively). (17:41)

The old person's reconciliation and self content is affected by his opinions about his health, economic level, his relationship to community especially family and managing his objectives suitable for his life as self content has three fields: positive emotional status, lack of negative emotions, life satisfaction. (16:5)

Quality of life can be expected in old people via many indicators including: emotional support, financial resources, life positive meaning, applying recreational activities, natural environment, social relationships, and developing objectives. (15 : 141)

Of course, applying activities and hobbies for old people mat improve their psychosocial status and memory and making use of spare time. $(25: 874)$

Quality of life old people is affected by social relationships, social roles, recreational activities, enjoying a good mental health, home, district, financial circumstances, independence, absolute freedom at house an in community, satisfaction, happiness, company, familiarity, love, social communication and participation and security feeling. $(9: 827)$

\section{Conclusions:}

Under the study objectives and results, the researchers concluded the following:

- Using the suggested program improved the following measurements (cholesterol triglycerides - useful cholesterol - harmful cholesterol - cretin - totl lipids fasting sugar - Glycated hemoglobin - urea - hemoglobin - red blood corpuscles - hematocrete - white platelets - tbrs - totlntioxidnt - W.B.CsTOTL) for the study sample

- Using the suggested program improved the study sample quality of life

\section{Recommendations:}

Under the research conclusions, the researchers recommend the following:

- Caring of old people as this group has special requirements.

- Using the suggested program in clubs and youth centers. 
- Motivating old people to apply recreational programs.

- Caring of old people food supplements.

- Cooperation between faculty of physical education and old age hospitals to make similar programs.

\section{References :}

Abd elm onim

Ashour

Abou Elela

Ahmed

Abdelfattah

Carruthers \&

Hood

Coalter et al

Gabriel \&

Bowling mg

Gaffer Hassan

Ageing

Hebbel

Low \& Malzahn

Mahmoud Ismail

Tola

Mary Abdalla

Habib

Peak

Singh

Rumpus \& Charoen
Old People's Health How Can it be Cared of, Egyptian Book Authority, Cairo, 2009

Physiology of Athletic Training, Dar El Faker El Arabi, Cairo, 2003

Building a life of meaning through therapeutic recreation: The leisure and well being model, Part I. Therapeutic Recreation Journal 41 (4): 276- 297, 2007.

The role of sport in regenerating deprived urban areas (Edinburgh, Scottish Office Central Research Unit), 2000 . Puality of life from the perspectives of older people. Againg \& society, 24, 678-691, 2004 .

Ageing, Age of Hope and Permanent Use, El Bahar Publishing House, Beirut, Lebanon, 2003

"Grannie's got to go fishing": Meanings and experiences of family leisure for three generation families in rural and urban settings. World Leisure Journal 56 (1): 42- 61, 2014 .

Predictors of quality of life in old age: across-validation study. Research in Nursing \&Health,30, 141-150, 2007.

Psychology of Recreation and Spare Time, Islamic Graphic, Cairo, 2010

Quality of Life from the Perspective of Egyptian University Girl, Magazine of Current Psychology and Human Science, issue (34), 2008

Food awareness, consumer responsibility Themternational Review of Research in Open and Distance Learning, 2012 .

Psychosocial problems: An issue among the elderly in Kathmandu, Nepal. International Journal of Health Sciences and Research, 3, 48-53, 2013.

Knowledge, Awareness and Practice about Food and Nutrition of Adolescence in Muang District, Prachinburi Province, Faculty of Home Economics Technology, Raja Mangala University of Technology Pura Nakhon , 2014 . 